\title{
EVALUATION OF THE SOCIAL ENVIRONMENT AND ACCESS TO FINANCIAL RESOURCES FOR BUSINESS: CASE STUDY OF THE CZECH AND SLOVAK REPUBLIC
}

\author{
Jan Dvorsky ${ }^{1, a, *}$, Gabriela Sopkova ${ }^{2, b}$ and Monika Janoskova ${ }^{3, c}$ \\ ${ }^{1}$ Tomas Bata University in Zlin, Faculty of Management and Economics, Department of Enterprise \\ Economics, Mostní 5139, 76001 Zlín, Czech Republic \\ ${ }^{2}$ University of Economics in Bratislava, Faculty of Commerce, Department of International Trade, \\ Dolnozemská cesta 1, 85235 Bratislava 5, Slovakia \\ ${ }^{3}$ Tomas Bata University in Zlin, Faculty of Management and Economics, Department of Enterprise \\ Economics, Mostní 5139, 76001 Zlín, Czech Republic \\ aj1dvorsky@fame.utb.cz, ${ }^{b}$ gabriela.sopkova@euba.sk, ${ }^{c}$ monika.janoskova.mj@gmail.com \\ *Corresponding author
}

\begin{abstract}
The growing amount of businesses and the increasing number of businesses in the countries of central Europe in the first two decades of the 21 st century has resulted in the expansion of study programs of economics. The inclination of these entrepreneurs to start a business is affected by several factors. A university education does not guarantee that a student after completion of a university course of study will become an entrepreneur. One of the important factors is the perception of the social environment and access to financial resources in the country of the student. The comparison of attitudes of students in the Czech and Slovak Republics to the social environment as well as the relationship of students to entrepreneurship is the aim of the article. The research sample represented 409 students from 14 universities active in the Czech Republic and 568 students acting at universities in the Slovak Republic. For the verification of the statistical hypotheses descriptive characteristics of statistics and the methods of mathematical statistics were used. In the conclusions, the authors summarize the basic common characteristics and the diversity of the perception of the social environment between selected countries.
\end{abstract}

Keywords: Students from universities, social environment, financial resources, Business.

JEL Classification: M13, D83.

\section{Introduction}

Amongst the challenges, we can put the issue of the applicability of university students in professional life and their real potential tend to their future entrepreneurial activities and activities. Graduates of economic subjects should be one of the driving forces of the economy and the economy of each country, on the basis of their acquired knowledge and natural intellect. Prospective future entrepreneurs belong to the group of people who through their creativity help their country to progress. Factors that affect the entry of a young person into the business environment include the social environment, state support for entrepreneurship, microeconomic environment, access to financial resources, quality education for all, personality qualities, the quality of the business environment and the other. 
In this article we are examining how social environment determines the tendency of the university students to do business in the Czech and Slovak Republic.

The structure of the article is the following. In a review of the literature, the authors present the results of research in the field of factors in social protection. In the following sections, we have set ourselves the goals of research and methodology; we have described the data and have selected the methods to verify the questions of statistical hypotheses used to evaluate the main objectives of the article. In the third part, we present the results of our research and their interpretation. In the last part of the contribution, we formulate the basic conclusions of the perception of the social environment as one of the factors which determines the inclination to do business.

\section{The theoretical part}

A great number of autors stated that small and medium-sized enterprises (SMEs) are undoubtedly an essential part of any market economy (Czarniewski, 2016, Haviernikova et al., 2016, Belás \& Sopková, 2016, Kozubikova et al., 2015, Karpak, 2010). According to Kessler (2007), the SMEs are a key factor in maintaining and creating a functioning market economy, particularly as a means of stimulating competition, creating jobs and promoting economic development. They also contribute to solving the problems of the economic and social state, thinks Prasetyo (2016).

Norris F. Krueger et al. (2000) describe the business as a way of thinking when those who want to start a business must perceive more opportunities than threats. In this case, it is important that a potential entrepreneur was able to isolate the right opportunity for setting up a business; in the vast majority of cases, to find a niche in market that would be filled and to take such a strategic position which is suitable for a good start to enter the market.

Many different researches have confirmed that entrepreneurs who completed their higher education have substantially better prerequisites for business. Lafuente and Vaillant (2013) and Velez (2009) suggest that university educated people are more interested in the possibility of running their own businesses compared to those with lower levels of education. Naude et al. (2008) assert that higher education represents an important positive factor for entrepreneurship since such educated individuals are capable to see more market opportunities which affect the positive economic growth of the company (Rauch \& Rijsdijk, 2013). Higher education is also correlates positively with higher sales, profitability and sustainability of the company (Van der Sluis \& Van Praag, 2008). Millian et al. (2014) report that educated entrepreneurs are more capable of attracting educated employees for their business, which has a positive effect on the return and productivity of the company. Previous researches confirmed that entrepreneurs with higher education perceive the intensity of factors shaping business environment differently as they have better prerequisites for managing business and financial risks in companies (Belás et al., 2016; Ključnikov \& Belás, 2016).

The result of the work of Jones, Miller, Packham \& Zbierowsky (2011) suggests that entrepreneurship education at universities can have a positive impact on the intentions of students to be entrepreneurs. It is more likely that education can increase the level of confidence of students and motivate them to choose entrepreneurship as an alternative to simple occupation. The same opinion was expressed by authors like Popescu, Bostan, Robu, Maxim \& Diaconu in their contribution in 2016. 
Lenaro et al. (2015) tested models for business career. They in particular assumed that business interests affect future career choices and their awareness of their own efficiency is associated with the results of the expectations and both these constructs affecting the interests and the choice of their careers. This article further examines the differences in these variables and tests the generalisation of relations among students for both business and non-business disciplines. But the interests are not associated with the choice of employment, while the effect of expectations depends on the external / internal nature and academic orientation of the student.

Belás (2016) shows that that the perception of the social environment in the country ranks among the three most significant tendencies of the students to run their own business. Gurol (2006) argues that a significant determinant of the inclination of the young people to start a business includes access to financial resources in the country.

The research findings of Robertson (2000) in Australia show that the perception of the business environment and their support by politicians is important in deciding to start a business. And this applies especially for young people after graduation.

The output of the Case Study Westhead (2016) is that medial and communication tools and their presentation in the society rank among the significant effects involving the start of the business. The results confirmed the different perceptions of men and women, as well as of those of various countries of the European Union. Gupta et al. (2014) also confirmed by his research in Turkey that students' perceptions of the social environment are different from the student's country of origin.

Franke (2004) and Karimi (2016) both list other factors such as the perception of entrepreneurs by society and family. Family environment and background is the most important factor for starting a business, states Lafuente (2013) in his research results. This concurs with this view and that of $\mathrm{Wu}$ (2008), who carried out research on the incline of the students to business in China.

Dacin et al. (2016) state that the most important determinants of the inclination of the students to entrepreneurship include financial resources and access to them. It also shows that this involves an approach of state aid in the country, access of the banking sector business entities and access of the future entrepreneurs to search for alternative financial resources for business.

\section{Objective, Methodology and Data}

The aim of this article is based on the acquisition of attitudes from university students in the Czech Republic to compare the social environment and access to financial resources in the country as factors that affect their tendency to start a business.

In the context of the stated goal of the research, we have assessed student attitudes by the polling method with a form of completing the online questionnaire, which operates in recent years of study at universities and colleges in the Czech and Slovak Republic. The questionnaire was completed by 409 students from 14 universities in the Czech Republic and 568 students from 8 universities in the Slovak Republic.

The following universities (U) were represented:

- From the Czech Republic - Technical University of Liberec, University of Applied business - Newton College in Brno, University of Economics in Prague, private university business in Prague, Masarykova University in Brno, Academia Sting in 
Brno, University of Business and Law in Prague, Palacky University in Olomouc, University Pardubice, University of mining - Technical University Ostrava, Technical University in Brno, Tomas Bata University in Zlin, Moravian University in Olomouc, Mendel University in Brno,

- From the Slovak Republic - Economic University in Bratislava, Trenčin University of Alexander Dubček in Brno, Žilina university in Žilina, Prešov University in Prešov, University Dorčić-Bubulić Bela in Banska Bystrica, Technical Faculty of the Technical University in Košice, pan-European University in Bratislava.

In the framework of our research, we have set five scientific hypotheses by method of expert estimate:

- H1: More than $50 \%$ of students believe that they are going to start their businesses after the end of all studies. There are statistically significant differences in the positive responses of students in the Czech and Slovak Republic.

- H2: More than 50\% of students have an entrepreneur in the family and appreciate his work. There are no statistically significant differences in the positive responses of students in the Czech and Slovak Republic.

- H3: More than $50 \%$ of students think that society in their country appreciates entrepreneurs and their business activities. There are statistically significant differences in the positive responses of students in the Czech and Slovak Republic.

- H4: More than $50 \%$ of students think that politicians and public opinion in the country well recognizes the contribution of entrepreneurs to society. There are statistically significant differences in the positive responses of students in the Czech and Slovak Republic.

- H5: More than $50 \%$ of students think that the media is properly and fairly giving information on the status and activities of entrepreneurs. There are no statistically significant differences in the positive responses of students in the Czech and Slovak Republic.

- H6: More than $50 \%$ of students think there is a heavy financial risk in the business environment. There are no statistically significant differences in the positive responses of students in the Czech and Slovak Republic.

- H7: More than 50\% of students think that the business entities have good access to bank credit. There are statistically significant differences in the positive responses of students in the Czech and Slovak Republic.

- H8: More than $50 \%$ of students consider the credit terms of the commercial banks in their country as appropriate. There are statistically significant differences in the positive responses of students in the Czech and Slovak Republic.

- H9: More than 50\% of students think that interest rates of the commercial banks support business activities. There are no statistically significant differences in the positive responses of students in the Czech and Slovak Republic.

We want to know what effect a social environment (family relationships, association, politicians, media) has on the tendency to do business. The initial assumption is that these elements of the social environment and access to financial resources are the most important factors.

The social environment:

- K11: I have a businessman in the family and I appreciate his/her work. 
- K12: The society (people in general) appreciates entrepreneurs.

- K13: Politicians and public opinion properly understand the benefits of entrepreneurs to society.

- K14: The media correctly and properly inform people on the status and activities of entrepreneurs.

Access to financial resources:

- K21: There is no heavy financial risk in the business environment; this is the wrong approach to external sources of finance, poor payment discipline, etc.

- K22: Business entities have good access to bank credit.

- K23: I consider the terms of credit of the commercial banks in my country as appropriate.

- K24: The interest rate of the commercial banks supports business activities.

Students could express their opinions about their inclination at the end of their studies through responses to claims:

- KY: I believe, I can start my own business after the end of all my studies.

For the evaluation of the questions of statistical hypotheses needed to meet the main objectives of the article, we used tools of descriptive statistics such as table and descriptive characteristics (frequency, amount), which are necessary for the calculation of Z- score. To arrive at the solution, we have used a simple sorting of the statistical character with an emphasis on the expression of the absolute and relative frequencies, sorting according to two statistical characteristics of the relationship between the quality (plural) statistical characters (Betáková et al., 2014). Statistical hypotheses we adopted or rejected on the set level of significance (boundaries of the hypothesis) with p- value 0.05 (Hudáková et al., 2015). We have applied the $\mathrm{Z}$-score into the process of evaluation and identification of significant statistical differences on individual constructs (K11, K12, K13, K14 and KY) among students in the Czech and Slovak universities. The conditions for carrying out the $\mathrm{Z}$ test (normal distribution of statistical character and a broad range of sample) were met. Calculations were made through sophisticated statistical software SPSS Statistics.

\section{Results}

The table below gives the results of the evaluation of the social environment as a factor which may influence the decision whether a student at the end of all studies starts in his or her own business.

\begin{tabular}{|c|c|c|c|c|c|}
\hline $\begin{array}{c}\text { K11: I have a } \\
\text { businessman in the family } \\
\text { and I appreciate his/her } \\
\text { work. }\end{array}$ & $\mathrm{CR}$ & SR & $\begin{array}{l}\text { K12: The society (people } \\
\text { in general) appreciates } \\
\text { entrepreneurs. }\end{array}$ & $\mathrm{CR}$ & SR \\
\hline 1. I agree completely & 173 & 199 & 1. I agree completely & 17 & 31 \\
\hline 2. I agree & 105 & 191 & 2. I agree & 161 & 234 \\
\hline $\begin{array}{l}\text { The ratio of the } 1+2 \text { to } \\
\text { the total }[\%]\end{array}$ & $\begin{array}{l}278 \\
68.0 \%\end{array}$ & $\begin{array}{l}390 \\
68.7 \%\end{array}$ & $\begin{array}{l}\text { The ratio of the } 1+2 \text { to } \\
\text { the total }[\%]\end{array}$ & $\begin{array}{l}178 \\
43.5 \%\end{array}$ & $\begin{array}{l}265 \\
46.7 \%\end{array}$ \\
\hline 3. No attitude & 70 & 90 & 3. No attitude & 93 & 138 \\
\hline 4. I disagree & 35 & 63 & 4. I disagree & 129 & 154 \\
\hline
\end{tabular}




\begin{tabular}{llllll} 
5. I do not agree at all & 26 & 25 & 5. I do not agree at all & 9 & 11 \\
\hline Together & 409 & 568 & Together & 409 & 568 \\
\hline $\begin{array}{c}\text { K13: Politicians and } \\
\text { public opinion properly } \\
\begin{array}{c}\text { understand the benefits of } \\
\text { entrepreneurs to society. }\end{array}\end{array}$ & CR & SR & $\begin{array}{c}\text { K14: The media correctly } \\
\text { and properly inform people } \\
\text { on the status and activities of } \\
\text { entrepreneurs. }\end{array}$ & CR & SR \\
\hline $\begin{array}{l}\text { 1. I agree completely } \\
\text { 2. I agree }\end{array}$ & 7 & 7 & 1. I agree completely & 2 & 7 \\
$\begin{array}{l}\text { The ratio of the 1+2 to } \\
\text { the total [\%] }\end{array}$ & 116 & 106 & 2. I agree & 27 & 75 \\
3. No attitude & $18.8 \%$ & 113 & The ratio of the $1+2$ to & 29 & 82 \\
4. I disagree & 116 & 154 & 3. No attitude & $7.1 \%$ & $14.4 \%$ \\
5. I do not agree at all & 183 & 248 & 4. I disagree & 208 & 27 \\
\hline Together & 33 & 53 & 5. I do not agree at all & 51 & 39 \\
\hline
\end{tabular}

Explanatory notes: $C R$ - Czech Republic, SR - Slovak Republic. Source: own processing

From the results of the questionnaire survey of students' attitudes towards the social environment in the country, we came to these partial interpretations:

- a comparable number of students (68\% in the Czech Republic, $68.7 \%$ in the Slovak Republic) have a businessman in the family and at the same time appreciate his/her work,

- More than 4 of 10 students (regardless on the country of residence of the student) think that the company appreciates the work of entrepreneurs,

- students in the CR are more convinced that the company appreciates the work of entrepreneurs, relative to the views of the students in the SR $(2.8 \%)$,

- less than 2 of 10 students agree with the statement (irrespective of the country of the student) that politicians and public opinion correctly understand the benefit of entrepreneurship for society,

- less than 1 of 10 students at universities in CR agree with the statement that the media correctly and properly inform on the status and activities of entrepreneurs in the country,

- students operating in universities in the Czech Republic more agree with the statement that the media correctly and properly inform on the status and activities of entrepreneurs in the country (the difference is up to $7.3 \%$ ).

Table 2: Comparison of evaluation of access to financial resources by university students

K21: In the business

environment, there is not

heavily financial risk: this is

the wrong approach to

K22: Business entities

external sources of finance,

good access to bank credit.

poor payment discipline, etc.

\begin{tabular}{|c|c|c|c|c|c|}
\hline 1. I agree completely & 7 & 14 & 1. I agree completely & 25 & 23 \\
\hline 2. I agree & 105 & 113 & 2. I agree & 217 & 270 \\
\hline $\begin{array}{l}\text { The ratio of the } 1+2 \text { to } \\
\text { the total }[\%]\end{array}$ & $\begin{array}{l}112 \\
27.4 \%\end{array}$ & $\begin{array}{l}127 \\
22.4 \%\end{array}$ & $\begin{array}{l}\text { The ratio of the } 1+2 \text { to } \\
\text { the total }[\%]\end{array}$ & $\begin{array}{l}242 \\
59.2 \%\end{array}$ & $\begin{array}{l}293 \\
51.6 \%\end{array}$ \\
\hline 3. No attitude & 122 & 137 & 3. No attitude & 105 & 172 \\
\hline 4. I disagree & 155 & 262 & 4. I disagree & 60 & 93 \\
\hline 5. I do not agree at all & 20 & 42 & 5. I do not agree at all & 2 & 10 \\
\hline Together & 409 & 568 & Together & 409 & 568 \\
\hline
\end{tabular}




\begin{tabular}{|c|c|c|c|c|c|}
\hline $\begin{array}{l}\text { K23: I consider the } \\
\text { terms of credit of the } \\
\text { commercial banks in my } \\
\text { country as appropriate. }\end{array}$ & CR & SR & $\begin{array}{l}\text { K24: The interest rate of } \\
\text { the commercial banks are } \\
\text { supporting business } \\
\text { activities. }\end{array}$ & $\mathrm{CR}$ & SR \\
\hline 1. I agree completely & 13 & 12 & 1. I agree completely & 10 & 23 \\
\hline 2. I agree & 216 & 267 & 2. I agree & 178 & 199 \\
\hline $\begin{array}{l}\text { The ratio of the } 1+2 \text { to } \\
\text { the total }[\%]\end{array}$ & $\begin{array}{l}229 \\
56.0 \%\end{array}$ & $\begin{array}{l}279 \\
49.1 \%\end{array}$ & $\begin{array}{l}\text { The ratio of the } 1+2 \text { to } \\
\text { the total }[\%]\end{array}$ & $\begin{array}{l}188 \\
46.0 \%\end{array}$ & $\begin{array}{l}222 \\
39.1 \%\end{array}$ \\
\hline 3. No attitude & 112 & 173 & 3. No attitude & 145 & 211 \\
\hline 4. I disagree & 62 & 108 & 4. I disagree & 73 & 125 \\
\hline 5. I do not agree at all & 6 & 8 & 5. I do not agree at all & 3 & 10 \\
\hline Together & 409 & 568 & Together & 409 & 568 \\
\hline
\end{tabular}

The results of the questionnaire survey of students' attitudes towards access to financial resources in the country, are listed below:

- Students in the Czech Republic evaluated the intensity of the financial risk more negatively in comparison than students who work in the Slovak Republic (the difference in the Czech Republic: $27.4 \%$ and SR: $22.4 \%$ )

- More than $50 \%$ of students, irrespective of the country of the scope, believe that business operators have good access to bank credit (CR: 59.2\%, SR: 51.6\%),

- The greatest differences in the number of students between the Czech Republic and the Slovak Republic are in the evaluations of the claim that the credit terms and conditions of the commercial banks are appropriate in the respective country.

- More than 5.5 out of 10 addressed students (working in universities in the Czech Republic) think that the credit conditions of commercial banks are adequate in the Czech Republic; it is fewer than 5 students in the Slovak Republic,

- Fewer than 5 out of 10 addressed students working at universities in the Czech Republic or the Slovak Republic agree with the statement that commercial bank interest rates support entrepreneurial activities.

In the previous two tables (Tab. 1 and Tab. 2), we have shown a comparison of determinant research results (social environment and access to financial resources) that can influence student decisions when starting a business. In Tab. 3, the authors present the results of the students tendency to start a business after completion of a university course of study.

Table 3: Tendency of students to start a business after completion of a university course of study.

\begin{tabular}{|c|c|c|}
\hline $\begin{array}{l}\text { KY: I believe, I can start my } \\
\text { own business after the end of all } \\
\text { my studies. }\end{array}$ & $\mathrm{CR}$ & SR \\
\hline 1. I agree completely & 33 & 46 \\
\hline 2. I agree & 77 & 157 \\
\hline $\begin{array}{l}\text { The ratio of the } 1+2 \text { to the } \\
\text { total }[\%]\end{array}$ & $\begin{array}{l}110 \\
26.9 \%\end{array}$ & $\begin{array}{l}203 \\
35.7 \%\end{array}$ \\
\hline 3. No attitude & 108 & 168 \\
\hline 4. I disagree & 145 & 148 \\
\hline 5. I do not agree at all & 46 & 49 \\
\hline Together & 409 & 568 \\
\hline
\end{tabular}

Explanatory notes: Czech Republic - Czech Republic, SR - Slovak Republic. Source: own processing 
In our research, $26.9 \%$ of students from the Czech Republic are convinced that they will start their own business after the end of their university studies. Fully $35.7 \%$ of students in the Czech Republic are convinced they will start their own business that after the end of their university studies. After successful completion of an economy study program, every third student will start his or her own business in the Slovak Republic; in the Czech Republic it is every fourth student.

In the following sections, we proceed to test the frequency response of students between countries using the methods of mathematical statistics.

Table 4: Tendency of students to start a business after completion of a university course of study.

\begin{tabular}{|c|c|c|}
\hline $\begin{array}{c}\text { The name of } \\
\text { the } \\
\text { construct }\end{array}$ & $\begin{array}{c}\text { Z-score / p-value } \\
\text { positive Answers } \\
\text { CR/SR }\end{array}$ & Interpretation of the Z-score \\
\hline K11 & $-0,229 / 0,818$ & $\begin{array}{l}\text { There are no statistically significant differences in the } \\
\text { responses among students by country of study. }\end{array}$ \\
\hline K12 & $-0,971 / 0,332$ & $\begin{array}{l}\text { There are no statistically significant differences in the } \\
\text { responses among students by country of study. }\end{array}$ \\
\hline K13 & $3,667 / 0,0003$ & $\begin{array}{l}\text { There are statistically significant differences in the } \\
\text { responses among students by country of study. }\end{array}$ \\
\hline K14 & $-3,569 / 0,0004$ & $\begin{array}{l}\text { There are statistically significant differences in the } \\
\text { responses among students by country of study. }\end{array}$ \\
\hline K21 & $1.869 / 0.069$ & $\begin{array}{l}\text { There are no statistically significant differences in the } \\
\text { responses among students by country of study. }\end{array}$ \\
\hline K22 & $2.480 / 0.0183$ & $\begin{array}{l}\text { There are statistically significant differences in the } \\
\text { responses among students by country of study. }\end{array}$ \\
\hline K23 & $2.243 / 0.0321$ & $\begin{array}{l}\text { There are statistically significant differences in the } \\
\text { responses among students by country of study. }\end{array}$ \\
\hline K24 & $2.250 / 0.0317$ & $\begin{array}{l}\text { There are statistically significant differences in the } \\
\text { responses among students by country of study. }\end{array}$ \\
\hline KY & $-2,992 / 0,0035$ & $\begin{array}{l}\text { There are statistically significant differences in the } \\
\text { responses among students by country of study. }\end{array}$ \\
\hline
\end{tabular}

Explanatory notes: $C R$ - Czech Republic, SR - Slovak Republic. Source: own processing

The results indicate that among students looking at universities in the Czech and Slovak Republics, there are different perceptions of the social environment and about access to financial resources for business.

\section{Discussion}

There are statistically significant differences in the frequency of students between countries, who were start my own business after the end of all my studies. But their number or in one country does not constitute a percentage greater than $50 \%$. We partially accept the $\mathrm{H} 1$ hypothesis.

The results show that there are no statistically significant differences between the assessments of students in the Czech Republic and the Slovak Republic, where said student has a businessman in family and appreciates his work. In both countries, more than $50 \%$ of all of those surveyed students agreed. We accept the $\mathrm{H} 2$ hypothesis.

Also the Tab. 4 shows that there are no statistically significant differences in the frequency of students who positively responded to the claim that their wider environment (company) 
appreciates entrepreneurs. The number of respondents in any country does not exceed $50 \%$ of students. We reject the $\mathrm{H} 3$ hypothesis.

There are statistically significant differences in the frequency of students between countries who positively responded to the claim that politicians and public opinion properly understand the benefits of entrepreneurs to society. However, their number or in one country does not constitute a percentage greater than $50 \%$. We partially accept the $\mathrm{H} 4$ hypothesis.

There are statistically significant differences in the frequency of students between countries who positively responded to the claim that the media correctly and properly informed about the status and activities of entrepreneurs. But their number in one country does not constitute a percentage greater than $50 \%$. We reject the $\mathrm{H} 3$ hypothesis.

The results show that there are no statistically significant differences between the assessments by students in the Czech Republic and the Slovak Republic to the argument that the business environment is heavily affected by financial risk. In both countries, less than $50 \%$ of all of those surveyed students agreed. We partially accept the H6 hypothesis.

Also from the Tab. 4, it can be shows that there are statistically significant differences in the frequency of students who positively responded to the claim that the business entities have good access to bank credit. The number of respondents in both countries exceeded $50 \%$ of students. We accept the $\mathrm{H} 7$ hypothesis.

There are statistically significant differences in the frequency of students between countries who positively responded to the claim that We consider the credit terms of the commercial banks in my country as appropriate. But their number represents the percentage of more than $50 \%$ just in the CR. We partially accept the H8 hypothesis.

There are statistically significant differences in the frequency of students between countries who positively responded to the claim that the interest rate of the commercial banks supporting the business activities. But their number or in one country does not constitute a percentage greater than $50 \%$. We reject the $\mathrm{H} 9$ hypothesis.

\section{Conclusion}

The aim of this article is to compare the perception of the social environment and access to financial resources of the tendency toward a business in the Czech and Slovak Republic. Between the selected determinants of factors, the "social environment" in the country has been selected: position of politicians and the position of the company to the business impact of the family environment and the media. Between the selected determinants of factors, "access to financial resource" in the country have been selected: the financial risks in the business environment, businesspeople have access to bank credit, credit terms of commercial banks.

The results of our study yielded interesting findings. Students at universities in the Czech Republic were more positive in their perception of the social environment in their country as compared with the students acting at universities in the Slovak Republic. The larger percentage of the number of students in the Czech Republic who completed their education is decided to start a business compared to the students in Czech Republic. There are significant differences in the perception of the students on their claims that the media correctly and properly informed the public of the status and activity of entrepreneurs. In this regard, the consulted students in the Czech Republic are more sceptical, unlike students acting at universities in the Slovak 
Republic. The same conclusion can be observed also in the position of politicians and around public opinion.

\section{Acknowledgement}

The allowance has been processed in the framework of the IGA/FaME/2017/006.

\section{References}

[1] Belás, J., Vojtovič, S., \& Ključnikov, A. (2016). Microenterprises and Significant Risk Factors in Loan Process. Economics and Sociology, vol. 9, no. 1, pp. 43-59. doi: 10.14254/2071-789X.2016/9-1/3

[2] Belás, J., \& Sopková, G. (2016). A Model of Entrepreneurial Orientation. Transformation in Business \& Economics, vol. 15, no. 2B (38B), pp. 630-645.

[3] Czarniewski, S. (2016). Small and Medium-Sized Enterprises in the Context of Innovation and Entrepreneurship in the Economy. Polish Journal of Management Studies, vol. 13, no. 1, pp. 30-39. doi: 10.17512/pjms.2016.13.1.03

[4] Dacin, P.A., Dacin, M.T., \& Matear, M. (2010). Social Entrepreneurship: Why We Don't Need a New Thory and How We Move Forward From Here. Academy of Management Perspectives, vol. 24, no. 3, pp. 37-57. doi: http://www.jstor.org/stable/29764973

[5] Franke, N., \& Luthje, C. (2004). Entrepreneurial Intentions of Business Students: A Benchmarking Study. International Journal of Innovation and Technology Management, vol. 1, no. 3, pp. 269-88. doi: 10.1142/S0219877004000209

[6] Gupta, V.K., Goktan, A.B., \& Gunay, G. (2014). Gender differences in evaluation of new business opportunity: A stereotype threat perspective. Journal of Business Venturing, vol. 29, no. 2, pp. 273-288. doi: 10.1016/j.jbusvent.2013.02.002

[7] Gurol, Y., \& Atsan, N. (2006). Entrepreneurial characteristics amongst university students: Some insights for entrepreneurship education and training in Turkey. Education + Training, vol. 48, no. 1, pp. 25-38. doi: 10.1108/00400910610645716

[8] Havierniková, K., Okręglicka M., \& Lemańska-Majdzik A. (2016). Cluster Cooperation and Risk Level in Small and Medium-Sized Enterprises. Polish Journal of Management Studies, vol. 14, no.2, pp. 82-92. doi: 10.17512/pjms.2016.14.2.08

[9] Jones, P., Miller, C., Jones, A., Packham, G., \& Zbierowski, P. (2011). Attitudes and motivations of Polish students towards entrepreneurial activity. Education + Training, vol. 53, no. 5, pp. 416-432. doi: 10.1108/00400911111147721

[10] Karimi, S., Biemans, H.J.A., Lans, T., Chizari, M., \& Mulder, M. (2016). The impact of entrepreneurship education: a study of Iranian students' entrepreneurial intentions and opportunity identification. Journal of Small Business Management, vol. 54, no. 1, pp. 187-209. doi: 10.1111/jsbm.12137

[11] Karpak, B., \& Tocku, I. (2010). Small medium manufacturing enterprises in Turkey: an analytic network process framework for prioritizing factors affecting success. International Journal of Production Economics, vol. 125, no. 1, pp. 60-70. doi: 10.1016/j.ijpe.2010.01.001 
[12] Kessler, A. (2007). Success factors for new businesses in Austria and the Czech Republic. Entrepreneurship and Regional Development, vol. 19, no. 5. doi: 10.1080/08985620701439959

[13] Ključnikov, A. \& Belás, J. (2016). Approaches of Czech Entrepreneurs to Debt Financing and Management of Credit Risk. Equilibrium. Quarterly Journal of Economics and Economic Policy, vol. 11, no. 2, pp. 343-365. doi: 10.12775/EQUIL.2016.016

[14] Kozubíková, L., Belás, J., Ključnikov, A., \& Virglerová, Z. (2015). Differences in approach to selected constructs of entrepreneurial orientation in SME segment regarding the selected socio-demographic factors. Transformation in Business nad Economic, vol. 14, no. 3C (36C), pp. 333-355.

[15] Lafuente, E.M., \& Vaillant, Y. (2013). Age Driven Influence of Role-Models on Entrepreneurship in a Transition Economy. Journal of Small Business and Enterprise Development, vol. 20, no. 1, pp. 181-203. doi: 10.1108/14626001311298475

[16] Lenaro, A., Vázquez, J.L., \& Aza, C.L. (2015). Social cognitive determinants of entrepreneurial career choice in university students. International Small Business Journal, vol. 34, no. 8, pp. 1053-1075. doi: 10.1177/0266242615612882

[17] Millian, J.M., Congregado, E., Roman, C., Van Praag, M., \& Van Stel, A. (2014). The Value of an Educated Population for an Individual's Entrepreneurship Success. Journal of Business Venturing, vol. 29, pp. 312-632. doi: 10.1016/j.jbusvent.2013.09.003

[18] Naude, W., Gries, T., Wood, E., \& Meintjiess, A. (2008). Regional determinants of Entrepreneurial Start-ups in a Developing Country. Entrepreneurship and Regional Development, vol. 20, pp. 111-124. doi: 10.1080/08985620701631498

[19] Krueger, N.F., Reilly, M.D., \& Carsrud, A.L. (2000). Competing models of entrepreneurial intentions. Jornal of Business Venturing, vol. 15, no. 5-6, pp. 411-432. doi: 10.1016/S0883-9026(98)00033-0

[20] Robertson, M., Line, M., Jones, S., \& Thomas, S. (2000). International students, learning environments and perceptions: A case study using the Delphi technique. Higher Education Research \& Development, vol. 19, no. 1, pp. 89-102. doi: $10.1080 / 07294360050020499$

[21] Popescu, C.C., Bostan, I., Robu, I.B., Maxim, A., \& Diaconu, L. (2016). An Analysis of the Determinants of Entrepreneurial Intentions among Students: A Romanian Case Study. Sustainability, vol. 8, no. 8. doi: 10.3390/su80807711

[22] Prasetyo, H.A. (2016). What driver international competitiveness? An empirical test in emerging Indonesian market. Journal of Competitiveness, vol. 8, no. 4, pp. 124-139. doi: 10.7441/joc.2016.04.08

[23] Rauch, A., \& Rijsdijk, S.A. (2013). The Effects of General and Specific Human Capital on Long-Term Growth and Failure of Newly Founded Businesses. Entrepreneurship Theory and Practice, vol. 37, no. 4, pp. 923-941. doi: 10.1111/j.1540-6520.2011.00487.x

[24] Van der Sluis, J., \& Van Praag, M. (2008). Education and Entrepreneurship Selection and Performance: A Review of the Empirical Literature. Journal of Economic Surveys, vol. 22, no. 5, pp. 795-841. doi: 10.1111/j.1467-6419.2008.00550.x 
[25] Velez, C.M. (2009). The Probability of Transition to Entrepreneurship Revisited: Wealth, Education and Age. Annals of Finance, vol. 5, pp. 421-441. doi: 10.1007/s10436-0080117-3

[26] Westhead, P., \& Solesvik, M.Z. (2016). Entrepreneurship education and entrepreneurial intention: Do female students benefit? International Small Business Journal, vol. 34, no. 8, pp. 979-1003. doi: 10.1177/0266242615612534

[27] Wu, S., \& Wu, L. (2008). The impact of higher education on entrepreneurial intentions of university students in China. Journal of Small Business and Enterprise Development, vol. 15, no. 4, pp. 752-74. doi: 10.1108/14626000810917843

[28] Betáková, J., Lorko, M., \& Dvorský J. (2014). The impact of the potential risks of the implementation of instruments for environmental area management on the development of urban settlement. Environmental Impact II, WIT Transcactions on ecology and the environment, vol. 181, pp.91-101. doi: 10.2495/EID140081

[29] Hudáková, M., Bugánová, K., Dvorský, J., Belás, J., \& Dana, L.P. (2015). Analysis of the risks of small and medium-sized enterprises in the Žilina region. Communications Scientific Letters of the University of Zilina, vol.17, no.1, pp. 34-39. 